\title{
Avaliação dos efeitos anti-inflamatórios e anticatabólicos do soro autólogo condicionado no tratamento clínico de osteoartrites em equinos atletas
}

Juliana Junqueira Moreira, Cynthia do Prado Vendrusculo, Patricia Monaco Brossi, Henrique Macedo Neuenschwander, Joice Fülber, Sarah Raphaela Torquato Seidel, Fernanda Rodrigues Agreste, Raquel Yvonne Arantes Baccarin

*Autor correspondente

e-mail: baccarin@usp.br

\section{Resumo}

A osteoartrite (OA) é o tipo de doença articular mais comum em humanos e equinos e causa mais frequente de claudicação, podendo levar à aposentadoria precoce dos animais acometidos. Atualmente, nenhuma terapia é totalmente eficaz no controle da cascata inflamatória e dos eventos catabólicos gerados pelas citocinas pró-inflamatórias, tampouco conseguem regenerar a cartilagem articular, comprometendo a função da articulação quando o animal retorna ao exercício. 0 soro autólogo condicionado (ACS), comercializado como Orthokine ${ }^{\circledR}$, IRAP I ${ }^{\circledR}$ e II ${ }^{\circledR}$, é um hemoderivado capaz de inibir a ação da interleucina-1 (IL-1), principal citocina inflamatória articular, uma vez que concentra grande quantidade do inibidor de receptor de IL-1 (IL-1ra), além de alguns fatores de crescimento. 0 objetivo deste estudo foi avaliar a resposta clínica e a ação anti-inflamatória e anticatabólica do IRAP II ${ }^{\circledR}$ em articulações sinoviais equinas com OA. Foram tratadas sete articulações metacarpo ou metatarsofalangeanas de equinos atletas, praticantes de salto, concurso completo de equitação e adestramento, e que apresentavam claudicação. A OA foi confirmada com exames ultrassonográficos, radiológicos e com bloqueio intra-articular (IA), analisado com o aparelho Lameness Locator $^{\circledR}$. Cada animal recebeu três aplicações IA de $4 \mathrm{ml}$ a cada 15 dias de IRAP II. Líquido sinovial (LS) foi coletado previamente ao bloqueio IA (D0), antes de cada tratamento (D15, D30) e 15 dias após o término (D45) para realização da contagem celular total, quantificação da prostaglandina E2 (PGE2), condroitim sulfato (CS) e ácido hialurônico (concentração e peso molecular). 0 exame ultrassonográfico ocorreu antes (D0) e ao final do tratamento (D45), juntamente com a análise da claudicação. Houve melhora da claudicação em todos os animais ao final do período de observação $(\mathrm{P}<0,05)$. Em todos os animais observou-se melhora significativa do escore relacionado às imagens ultrassonográficas $(\mathrm{P}<0,05)$ com menor distensão da cápsula articular, diminuição da quantidade de LS e membrana sinovial, demonstrando uma melhora da capsulite 
e sinovite associadas ao processo de OA, porém sem alterações da parte óssea e cartilagínea. Observou-se também redução na contagem celular em D45 (P < 0,05), embora as concentrações de PGE2 não tenham apresentado alterações, corroborando com a literatura. As concentrações de CS diminuíram em relação ao início do tratamento, demonstrado diminuição do catabolismo da matriz cartilagínea $(\mathrm{P}<0,05)$. Não houveram alterações significativas nas concentrações e pesos moleculares do ácido hialurônico. O IRAP II ${ }^{\circledR}$ demonstrou ser eficiente na promoção da melhora clínica e ultrassonográfica das articulações tratadas. Ainda, foi capaz de controlar a perda de CS decorrente do catabolismo cartilagíneo e o processo de sinovite e capsulite, apesar de não ter demonstrado ação sobre a inibição da produção de PGE2.

Palavras-chave: Cavalo. IRAP II. Líquido sinovial. 